\title{
The Roles of Agricultual Cooperatives in Linking Small Farmers to Set up Large Paddy Fields in Mekong Delta
}

\author{
Thi MinhVu \& Manh Dung Tran \\ National Economics University, Vietnam \\ Tien Dinh Nguyen \\ Institute of Policy and Strategy for Agriculture and Rural Development, Vietnam
}

\begin{abstract}
Agricultural cooperatives play a significant role in linking small farmers to set up large paddy fields in the Mekong Delta. Agricultural cooperatives' association for establishment of big paddy fields allows firms to purchase secured raw materials in mass quantities, ensuring quality while reducing related costs. Farmers are able to cut down the cost of production, sell products more effectively by gaining economy of scale and have higher position and influence over the businesses. In order to enhance the role of agricultural cooperatives in linking small farmers to establish large paddy fields in the Mekong Delta, it is necessary to synchronously implement the following solutions such as (i) improving mechanisms and policies for agricultural cooperatives to promote their role in farmer linkage to set up large paddy fields; (ii) strengthening the capacity of agricultural cooperatives management staff; iii) strengthening the role of agricultural cooperatives' representing member farmer households in carrying out the association with firms in setting up big paddy fields.
\end{abstract}

Keywords: Role of agricultural cooperatives, association, large paddy field, Mekong Delta

DOI: $10.7176 / \mathrm{JESD} / 10-2-12$

\section{Introduction}

With the nature of collective economic organizations, agricultural cooperatives (ACs) can improve the minor as well as scattered producting condition, and facilitate the development of large-scale agricultural production (Do, 2012, Vu, 2013). Various researches nationally and internationally (Motamed, 2010, ILO, 2009, Tang, 2012, Tran, 2012, Hoang, 2016), indicated that the association of farmers through ACs to set up large paddy fields (LPF) will provide all stakeholders with a great source of benefits: businesses can secure their purchase of mass quantity of raw materials, assure quality and reduce costs. As for the farmers, they can reduce the production cost, sell goods more effectively and gain influences and positions over the businesses. The ACs produce on large scale, work efficiently under the condition where land documentation belongs to the long-term use of the member households.

The Mekong Delta is the largest rice-producing region in Vietnam. However, the small scale of production leads to poor competitive ability in the international market, especially in terms of selling prices. One of the main causes may be the lack of ACs' role, so paddy farmers still mostly produce and sell their products to traders, triggering the high risks in production, consumption and income earning. Therefore, enhancing the role of ACs in farmer linkage for seting up concentrated commodity production areas such as LPF is an urgent requirement regarding paddy production in the Mekong Delta nowadays.

This research aims to (i) assess the actual status of the AC's role in linking farmers to set up LPF in the Mekong Delta; (ii) identify the economic benefits of ACs, farmers and enterprises in linkage to set up LPF of paddy production; (iii) Analyze the advantages, disadvantages and factors imfacting the role of ACs in the linkage to set up LPF in the Mekong Delta. (iv) Propose a number of suitable solutions to enhance the role of ACs in linking farmer to establish more LPF in the Mekong Delta in the upcoming period.

\section{Literature Review}

According to Eaton and Shepperd (2001), there are seven types of linkages beween farmers and the market: i) farmers and collectors/ traders; ii) farmers and retailers; iii) linkage by representative of farmers; iv) linkgages by cooperative; v) farmers and processor; vi) farmers and exporter ; vii) linkage by contract.

The research by Motamed (2010) has shown that cooperatives in Guilan state of Iran help their member househols use efficiently paddy land, inrcrese income through selling paddy at higher prices.

Falco et al. (2008) in the study on the role of cooperatives in diversification and productivity enhancement for in the southern Italia, stated that cooperatives can help private farmers earn more value from final products and better response to local custormers' demand through reducing transaction costs.

The study of Pratiwi (2015) agreed that cooperatives help coffe growers at Tenggara region of Indonesia to develop coffe production and processing through accesing financial sources, providing them with inputs, knowledge and market information.

Tosun et al. (2013) in their case studies of Taris olive oil and Tire milk cooperative models showed positive 
roles of cooperatives in providing services at lower costs, transfering knowleges, empowering bargaining powers and maximising added value to their members. Participation of cooperatives in value chains can help to increse selling prices, reduce price fluctuation not only for their members but aslo for the outsiders.

Dardak (2015) agrured that main problem of farmers with land area less than 1 ha in Malaysia is to have to participte in long supply chains with many intermediary actors. While farmers sell products at very low prices to intermediaries, consumers have to buy these products at very high ones. The author stated that well-organised agricultural cooperatives would reduce intermediary actors in the value chains and benefit famers by getting higher selling prices. He aslo showed that sustainability of cooperations within supply chain mainly dependent on participation of agricultural cooperatives.

The study of Song et al. (2014) stated that agricultual cooperatives in China facilitate farmers to do economic cooperation and market integration. In terms social aspect, horizontal linkages through cooperatives indicate solid cohesion, thus to increase level of industrilisation of agricultural management.

The International Labor Organization (2009) synthesized the role of cooperatives in linkaging agro-product value chains as folows of coperatives represent not only for their members but also tentatively for their location and country/nation. Cooperatives can enable enterprises be involved in their decision and regulation making processes. Further, cooperatives can link with banking system and service providers together in order to get better aggrements for their members.

However, above studies have not yet clearly clarified how ACs implememt their roles as well as which factors influencing the role of ACs in linking small farmers into value chains of agricultural products. In the context of Vietnam, Ho (2014) concluded that agricultural total productivity was significantly infuenced by land quality, farm size and land fragmentation. So the question of having large paddy fields for increasing productivity in agricultural field is getting more impartance.

\section{Research Methodology}

The study was conducted in four Mekong Delta provinces including An Giang, Hau Giang, Dong Thap and Bac Lieu, in which: i) 03 provinces of Hau Giang, An Giang, Dong Thap represent the Western sub-region of the Mekong Delta. This is the key paddy production area of the Mekong Delta, producing from 2 to three paddy crops per year. There are several models associating paddy production with consumption and set up of LPF in the provinces and many ACs, cooperative farmer groups, and farmer households participating the association for implementing LPF; ii) Bac Lieu province represents the coastal eastern sub-region of the Mekong Delta, which produces two paddy crops per year or paddy-shrimp intercropping.

The research was carried out in 2017, based on the survey results of $50 \mathrm{ACs}, 20$ cooperative farmer groups (FG); 13 enterprises consuming paddy; 139 rice-growing farmer households. The survey was conducted using standardized questionnaires. In addition, the study also conducted interviews with experts who are state management officers on $\mathrm{AC}$ in 4 surveyed provinces.

To analyze and clarify the role of ACs in linking farmer to create LPF in the Mekong Delta, the study had compared the four following association models: i) Model 1 (M1): cooperatives link farmers to establish LPF. This was the main research subject; ii) Model 2 (M2): cooperatives link farmers but not establish LPF (in reality, there are numerous cooperatives only do linkage of farmers, but do not build LPF); iii) Model 3 (M3): Farmer groups (FG) do association to build LPF; iv) Model 4 (M4): Enterprises contracted directly with individual farmers (free paddy producers and sellers, not being members of any cooperatives or FG).

The comparison between the models were to consider whether the differences between Model 1 and the remaining models are existent. In order to achieve this objective, the study used a statistical testing method to directly compare between Model 1 and the other models respectively (comparing the average of two independent groups) with $95 \%$ confidence.

\section{Results and Discussions}

4.1. The role of ACs in linking farmer to set up LPF in the Mekong Delta

(i) Promoting the accumulation and concentration of agricultural lands, forming the large-scale production areas

ACs implementing farmer association to construct LPF will promote the accumulation and concenstration of agricultural lands, which allow the formation of large-scale production regions to be easier than other kinds of linkages. So as to establish the large paddy production areas (LPF), the ACs in the Mekong Delta come in two forms: i) Cooperatives that rent the fields from the farmer households, then organize the production of the same seed types, following the unified technical process as required by the enterprises that AC has signed contract with. Typically, this is the case of Duc Hue Cooperative in Dong Thap province. ii) Cooperatives that identify 1 2 types of paddy varieties as required by the enterprise, then encourage the member households in the same field to produce those determined 1-2 variety types. After which, the cooperatives develop seasonal plans and guide farmers to apply the same technical processes (TP) of cultivation. This is another common practice of ACs in the 
Mekong Delta.

(ii) Organizing the collective activities to produce a mass volume of products, with equally assured quality and reduced production costs

Research results shown that agricultural cooperatives have diverse advantages when participating in the association to establish LPF. The role of agricultural cooperatives is demonstrated effectively in these stages: organizing farmers to coordinatedly sow 1-2 rice varieties in the crop on the LPF; organizing farmers to sow the same crop as planned; arranging farmers to harvest in the same period as planned. However, in the case of applying the general production TP; implementing the general cultivation practices on the use of fertilizers and chemicals; and applying synchonizedly several steps in rice production, the role of cooperatives is fainter. The reason is that many associated contracting businesses do not obligate the households to apply the same technical process, while on the other hand, farmers would not change their rice cultivation habits when required by enterprises and when the application of TP does not help increase profitability.

For the farmers to apply the uniformed farming practices, cooperatives often apply the following measures: i) Inform member households of the requirements of the associated enterprise. Accordingly, if the households agree to sign the contract with the enterprise, and the enterprise supports in advance the input materials, the households must follow the general farming practices as instructed by the enterprise; ii) Cooperatives promote and encourage people to implement; iii) Cooperative invite members to attend the meeting to learn of the businesses' requirements. Furthermore, cooperatives apply a number of other measures such as: requiring the implementation before offering small grants; notifying member households about the obligations of government agencies (agricultural encouragement, plant protection); delegating representatives to each household to persuade. Besides the imposition of requirements for farmers to apply the general cultivation practices as mentioned, the $\mathrm{AC}$ also provide services for paddy production to farmers participating in the LPF like pumping, watering; land preparation, leveling the field; sowing seeds; disease surveillance and offering guidance on paddy pest control; paddy harvesting and transportation services.

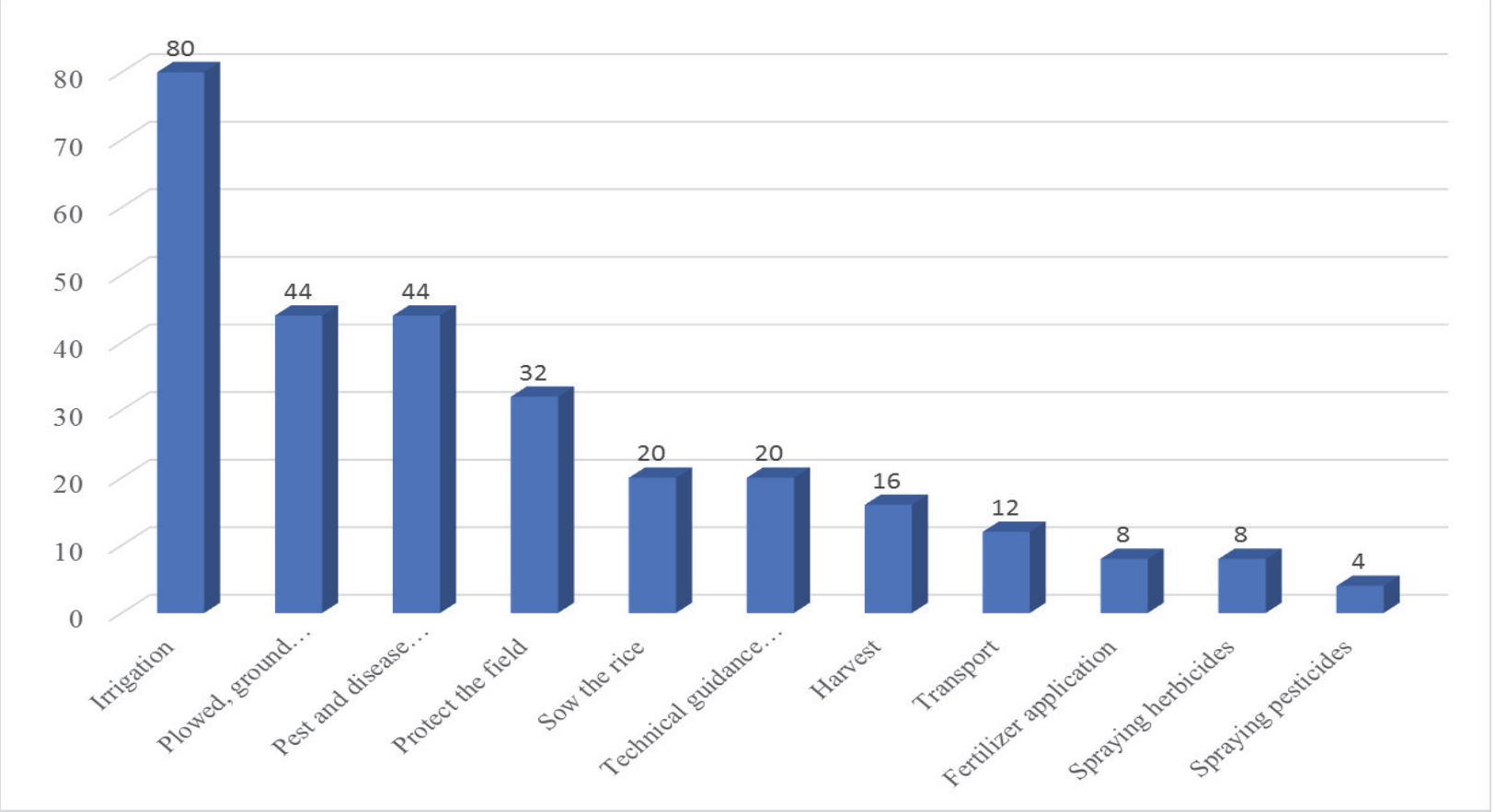

(Unit: \% ACs with services provided; $N=25$ )

Figure 1: Services the ACs provide to farmers in set up of LPF

(iii) ACs are the main intermediary factor, playing the role of linking and promoting vertical linkages with businesses

There are 03 types of ACs in farmer association to build LPF: i) Cooperatives only playing as an intermediary connection between farmer households and businesses (the intermediary receives commissions from businesses): accounted for $48 \%$ of total surveyed cooperatives; ii) Cooperatives making contracts for full purchase with farmers and businesses: took up to $6 \%$ of surveyed cooperatives; iii) Cooperatives representing members to negotiate and sign contracts for production and consumption of rice with businesses (concentrated consumption through cooperatives): $46 \%$ of surveyed cooperatives.

(iv) The role of ACs in coordinating and supervising the implementation of contracts with enterprises to consume paddy.

ACs also play an extremly significant role in signing and implementing contracts with enterprises, which 
were indicated through: representing the member households to negotiate and sign contracts for production and consumption of rice with enterprises; representing member households to negotiate the price of rice with the enterprises before the harvest time; receiving the advance investments from enterprises, re-granting to member households, and recovering debts from member households to repay the enterprises; representing member households to receive payment for the rice sales from businesses and return that to the farmers.

(v) ACs serve as a focal point for enterprises to invest in agriculture

When ACs associating farmers to establish LPF, businsses have many advantages such as: i) Not having to sign contracts with each farmer household, thereby reducing the associated costs; ii) Being able to build a stable material area, offering businesses the controls and improvements of product quality, so that purchasing materials becomes easy and convenient; iii) Reducing losses in recovering of advance investment debt; Restricting contract breaches by farmers who do not comply with commitments.

(vi) ACs in farmer association to set up LPF offer benefits to both the paddy farmers and cooperatives

\section{Benefits to paddy growers:}

First, increase farm productivity: Joining the association to set up LPF, most of the households believe that paddy productivity is higher than before; in which, the Model 1: AC associated to construct LPF (M1) shown that $79.6 \%$ of the surveyed households reported a higher productivity of paddy than that of prior to the association. The increase in such productivity was by $50 \mathrm{~kg} /$ ha averagely. The main reasons for increasing paddy yield is mainly due to three factors: i) the changes in paddy varieties (mainly from paddy varieties to high quality paddy varieties with quality certifications); ii) the application of new cultivating technical processes; iii) the instruction for paddy cultivation techniques. In addition, the productivity of paddy increased was also thanks to the cooperatives' provision with more efficient irrigation, drainage, spraying, and many other farming services. On the other hand, the increasing investment in fertilizer and pesticide is not the main reason for the increasing paddy yield.

Second, increase in paddy selling price: By switching to qualified paddy variety, changing the production technical processes when joining the contract of association to establish LPF, most farmers revealed that the price of paddy had risen by a higher proportion than when they were not involved in the association to build LPF. Specifically, statistical testing for the differences between groups of AC working in the association to set up LPF (M1) with the other 03 association models resulted in the P-value $<0.05$. Accordingly, cooperatives participating in LPF establishing association were proved to increase the paddy prices for farmers the most.

The average rise in price level of fresh paddy was $385 \mathrm{VND} / \mathrm{kg}$, of which the highest increase of 427 Vietnamese dong (VND)/kg was in the form of agricultural cooperatives joining the LPF establishment (M1). Such increase was primarily due to the fact that farmer members of AC were supplied with certified seed varieties by the cooperatives and were instructed in technical processes. Thus, the quality of paddy was better, more stable and uniformed, which allowed the selling price to grow more than that of non-association for construction of LPF.

Table 1: Changes in fresh paddy price of farmer households in LPF association

\begin{tabular}{|c|c|c|c|c|c|}
\hline Changes & $\begin{array}{c}\text { AC in } \\
\text { associati } \\
\text { on } \\
(\mathrm{M} 1) \\
n=49\end{array}$ & $\begin{array}{l}\text { AC in non- } \\
\text { association } \\
\quad(\mathrm{M} 2) \\
\quad n=47\end{array}$ & $\begin{array}{c}\mathbf{C G} \text { in } \\
\text { association } \\
(\mathrm{M} 3) \\
n=24\end{array}$ & $\begin{array}{l}\text { Businesses directly link with } \\
\text { farmers } \\
(\mathrm{M} 4) \\
n=19\end{array}$ & $\begin{array}{c}\begin{array}{c}\text { Overa } \\
\mathbf{l l} \\
n=139\end{array} \\
\end{array}$ \\
\hline $\begin{array}{lr}+ & \% \\
\text { households } & \\
\text { reporting } & \text { a } \\
\text { higher } & \text { price } \\
\text { level of } & \text { fresh } \\
\text { paddy } & \end{array}$ & 87,5 & $\begin{array}{c}77,8 \\
{[0.021]}\end{array}$ & $\begin{array}{c}95,7 \\
{[0.028]}\end{array}$ & $\begin{array}{c}78,9 \\
{[0.037]}\end{array}$ & 84,4 \\
\hline $\begin{array}{l}+ \text { Average rise } \\
\text { in price level of } \\
\text { fresh paddy } \\
\text { (VND / year) }\end{array}$ & 427 & $\begin{array}{c}353 \\
{[0.023]}\end{array}$ & $\begin{array}{c}368 \\
{[0.031]}\end{array}$ & $\begin{array}{c}369 \\
{[0.047]}\end{array}$ & 385 \\
\hline $\begin{array}{l}\text { * Note: Values } p \\
\text { Model. } \\
\text { Third, reduc } \\
\text { agricultural coop } \\
\text { paddy. According } \\
\text { costs, in which tl } \\
\text { association (M1) } \\
\text { paddy productio }\end{array}$ & $\begin{array}{l}\text { ced in }[] \\
\text { the cost } \\
\text { atives th } \\
\text { o the sur } \\
\text { percenta } \\
\text { ok acco } \\
\text { was abc }\end{array}$ & $\begin{array}{l}\text { P-value of } \\
\text { dy producti } \\
\text { ed the assc } \\
.1 \% \text { of hou } \\
\text { farmer hou } \\
\text { the most } \\
37 \text { million }\end{array}$ & $\begin{array}{l}\text { sponding } S \\
\text { nly increas } \\
\text { set up L } \\
\text { oncluded t } \\
\text { wo are me } \\
\text { f the conct } \\
\text { Neverthe }\end{array}$ & $\begin{array}{l}\text { al test between MI and each } \\
\text { oroductivity along with the se } \\
\text { o offer reduction in costs of } \\
\text { association helped cut down } \\
\text { of cooperatives in the LPF-e } \\
\text { louseholds). The cutback in } \\
\text { he findings of statistical te }\end{array}$ & $\begin{array}{l}\text { aining } \\
\text { price, } \\
\text { ducing } \\
\text { luction } \\
\text { lishing } \\
\text { ost of } \\
\text { of the }\end{array}$ \\
\hline
\end{tabular}


comparison between the model of cooperatives joined in the association to construct LPF (M1) and the model of enterprise directly associated with each farmer household (M4) returned the P-value $=0.154(>5 \%)$, meaning: the reduction in paddy production costs between the two models was not significantly different. The eplanation could be that, in Model 4, paddy farmers had to pay extra costs for seeds, fertilizers and pesticides. This was reflected in the case of Loc Troi Group where the farmers directly linked to it revealed that they had to buy seeds, fertilizers and pesticides supplied by the Group at a higher price than by other suppliers.

Table 2: Changes in paddy production costs of households after joining the LPF-establishing association

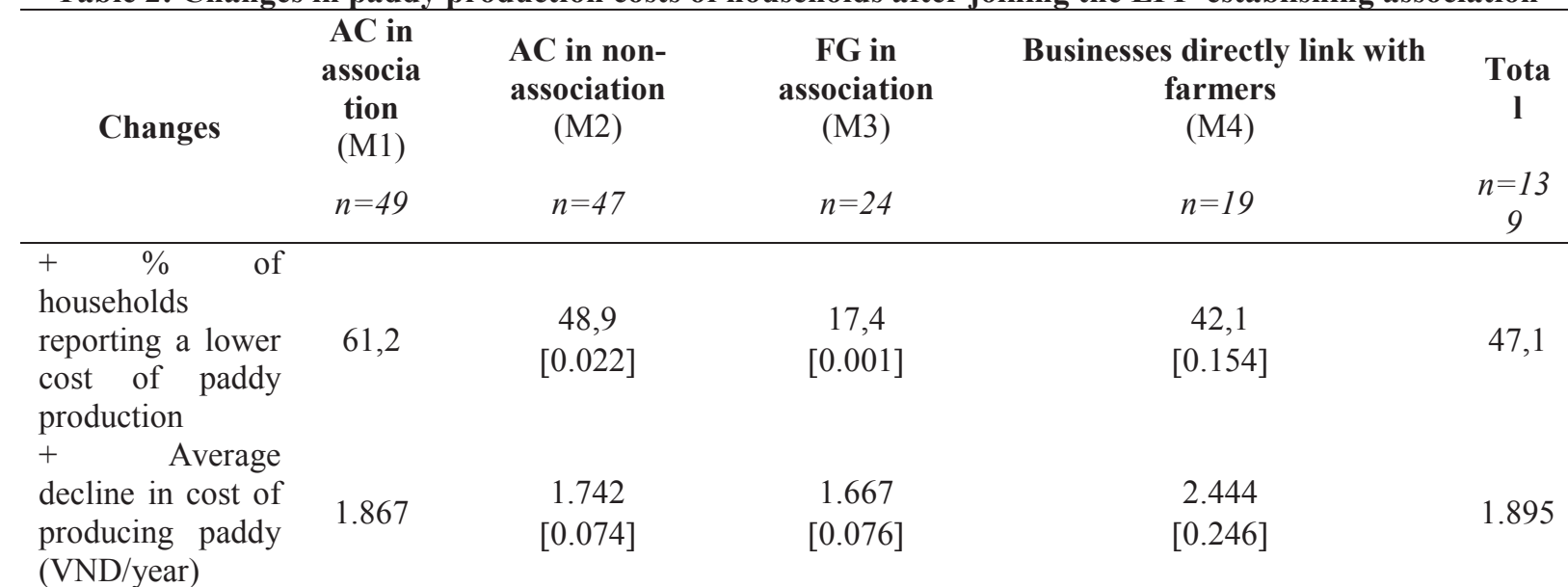

* Note: Values placed in [] is the P-value of the coresponding statistical test between M1 and each remaining Model.

Participating in the association to set up LPF, farmers were guided and applied uniformly practices of cultivation on the LPF namely 1M-5Rs (1M means Must use certified seeds; 5Rs mean Reductions in quantity of seeds, nitrogen fertiliser, chemical drugs of plant protection. water used and after-harvesting loss) and 3Rs-3Is (3Rs mean Reductions in quantity of seeds, nitrogen fertiliser and chemical drugs of plant protetion; 3Is mean Increase in rice produtivity, quality and economic eficiency), therefore cut down the amount of seed used, fertilizers and pesticides, which reduced service costs (soil preparation, pesticide spraying, irrigation, etc.). More specfically: i) Reducing seedling costs: In Model 1, $85.1 \%$ of households determined that seedling costs decreased. The answer for this was because of the cutback of seed amount used, thanks to the training to apply sustainable cultivation process provided when participating the LPF-establishing association (1M-5Rs and 3Rs3Is). In addition to less seed used, seed price also dropped, but it mainly happened in the 02 models with AC (M1 and M2). The explanation was, many cooperatives have organized seed production to sell to members; or cooperatives proceed to buy the seeds in bundle for the member households of the LPF association, so the price of seeds was less than when each household buy them individually from material agents; ii) Reducing costs of fertilizer and pesticides: As a result of the general technical process guidelines offered when attending the LPF association, farmers had considerablely reduced the costs for fertilizer and pesticide uses. The aforementioned reduction was mostly due to the fertilizer and pesticides usage cutback. Among the models with the participation of $\mathrm{AC}$, the percentage of farmers in the model of AC associated with LPF set up (M1) noted that the largest reduction in fertilizer and pesticide inputs were after participating in LPF association. The reason was that besides the training of farmers applying sustainable cultivation techniques (1M-5Rs and 3Rs-3Is), the cooperatives and the associated businesses also sent technicians to guide and monitor the use of pesticides of households on regular basis; iii) Reducing other costs: Thanks to the guidance of technical cultivation process, households were also able to reduce other costs such as: paddy production services (e.g: reduce the amount of pesticide sprays, thus cut down the rental or days for spraying); transportation costs from farm and warehouse of firms (supported by firms).

Fourth, inncrease profitability of paddy production: Increased productivity, increased selling prices and reduction of production costs gave rise to the profitability of paddy farmers. The survey results show that among the four LPF associated models, the form of business directly contracting with individual farmer households (M4) helped increase the profit of farmers the most, by 7 million VND/ha more compared to non-associated ones. However, because enterprises signed directly with each household, the enterprises paid more cost and effort than when signing it through agricultural cooperatives. Moreover, in the form of enterprises in Model 4, there was no centralized establishment of LPF, as in the same field, the enterprise only signed with a number of households. The remaining households, who did not sign contract with that enterprise, employed different seed varieties and cultivation techniques.

The model of AC in association with LPF establishment (M1) facilitated the profit of rice farmers by 6.1 million VND/ha, ranking second in 04 linkage models; The model of AC in non-association to set up LPF (M2) 
had the profit of farmers increased by only 3.5 million VND/ha; and the CG model (M3), the profitability of farmers increased by over 5 million VND/ha. To conclude, Model 1 with AC associated with LPF setup helps to form centralized production of commodity and centralized material areas for enterprises; while increases the profitability of paddy farming for farmers.

Table 3: Comparing the paddy production efficiency of households when attending association for LPF setup

\begin{tabular}{|c|c|c|c|c|c|c|c|c|}
\hline \multirow[t]{2}{*}{ Index } & \multicolumn{2}{|c|}{$\begin{array}{c}\text { AC in association } \\
\text { to set up LPF } \\
(\mathrm{M} 1) \\
n=49\end{array}$} & \multicolumn{2}{|c|}{$\begin{array}{c}\text { AC in association but not } \\
\text { set up LPF } \\
(\mathrm{M} 2) \\
n=47\end{array}$} & \multicolumn{2}{|c|}{$\begin{array}{c}\text { FG in } \\
\text { association } \\
\text { to set up LPF } \\
(\mathrm{M} 3) \\
n=24\end{array}$} & \multicolumn{2}{|c|}{$\begin{array}{c}\text { Businesses directly } \\
\text { link with farmers } \\
\text { (M4) } \\
n=19\end{array}$} \\
\hline & Before & After & Before & After & Before & After & Before & After \\
\hline $\begin{array}{l}+ \text { Crop yields } \\
\text { (ton per ha) }\end{array}$ & $\begin{array}{r}6.5 \\
(0.73) \\
{[0}\end{array}$ & $\begin{array}{l}6.9 \\
(0.72) \\
0]\end{array}$ & $\begin{array}{c}6.5 \\
(0.84) \\
{[}\end{array}$ & $\begin{array}{c}6.7 \\
(1.06)\end{array}$ & $\begin{array}{r}6,7 \\
(0.90) \\
{[0 .}\end{array}$ & $\begin{array}{l}7,1 \\
(1.04) \\
0]\end{array}$ & $\begin{array}{c}6,7 \\
(1.29)\end{array}$ & $\begin{array}{l}7,5 \\
(1.78) \\
]\end{array}$ \\
\hline $\begin{array}{l}+ \text { Price of fresh } \\
\text { paddy in the field } \\
(1.000 \mathrm{VND} / \mathrm{kg})\end{array}$ & $\begin{array}{r}5.3 \\
(0.50) \\
{[0}\end{array}$ & $\begin{array}{l}5.7 \\
(0.60) \\
0]\end{array}$ & $\begin{array}{c}5.2 \\
(0.30) \\
{[}\end{array}$ & $\begin{array}{c}5.5 \\
(0.40)\end{array}$ & $\begin{array}{r}5,1 \\
(0.30) \\
{[0 .}\end{array}$ & $\begin{array}{l}5,5 \\
(0.40) \\
0]\end{array}$ & $\begin{array}{c}5,2 \\
(0.30)\end{array}$ & $\begin{array}{l}5,5 \\
(0.20) \\
\end{array}$ \\
\hline $\begin{array}{l}+ \text { Total value of } \\
\text { paddy production } \\
\text { (million VND/ha) }\end{array}$ & [0.000] & $\begin{array}{l}39.4 \\
0]\end{array}$ & {$[0.000]$} & 37.1 & \multicolumn{2}{|c|}{$[0.000]$} & {$[0.012]$} & 41,3 \\
\hline $\begin{array}{l}+ \text { Total cost of } \\
\text { paddy production } \\
\text { (million VND/ha) }\end{array}$ & \multicolumn{2}{|c|}{ [0.501] } & \multicolumn{2}{|c|}{$[0.267]$} & \multicolumn{2}{|c|}{ [0.909] } & \multicolumn{2}{|c|}{$[0.585]$} \\
\hline $\begin{array}{l}+ \text { Profit of paddy } \\
\text { production } \\
\text { (million VND/ha) }\end{array}$ & \multicolumn{2}{|c|}{ [0.000] } & 14.6 & 18.1 & \multicolumn{2}{|c|}{$[0.001]$} & \multicolumn{2}{|c|}{ [0.069] } \\
\hline
\end{tabular}

* Note: Values in () represent standard deviation; Values in [] represent the P-value of the comparison tests for the pair of before and after participating in the LPF-establishing association in the corresponding model.

Fifth, farmers receive the supports from businesses: Participating in the association to build LPF, in addition to the benefits as described above, farmer members were also offered numerous other perks, namely: the paddy sales becoming more stable thanks to the association contracts, being provided by enterprises with advance assistances in cash and input materials, being supplied with input materials by the AC conveniently and at reasonable prices, securing quality, being guided with paddy cultivation techniques and supported to prevent diseases.

In the association to establish LPF, the supports of enterprises are crucial to both the people and the cooperatives. The survey indicated that, when participating in the association to construct LPF, paddy farmers are supported with advance investments (cash or inputs) which could be repaid using deferred payment method at the end of the crop, when selling paddy and the businesses charge no interest. Furthermore, a number of businesses allow the households to reserve paddy in storage within a month if the household does not want to sell paddy immediately after harvesting but want to wait for paddy prices to increase. However, very few firms such as Loc Troi Group have sufficient warehouse facilities to offer this support. In addition, some businesses even assist in covering the cost of paddy drying and/or the cost of transporting paddy from the field to their own warehouses. When the contract is signed, the company requires the cooperative to organize the transport of paddy from the field to the company's warehouse, then it will refund the shipping costs.

The level of support of enterprises for the households taking part in the association to set up LPF is relatively high. On average, enterprises provide cash advances or input materials to farmers with 9 million VND/ha worth. This support level accounts for $40.8 \%$ of the total cost of paddy production. This suggests that in order to encourage enterprises to join the association to build LPF, the State policies should impose favorable conditions for enterprises to request loans to support the LPF-establishing association.

In order to implement the association to set up LPF, besides providing cash advances and inputs for paddy production and other supports to farmers, businesses could also purchases paddy from farmers with a higher price than of the market during the same period. Thereby:

i) In the model of AC participating the LPF set up association (M1), $54.2 \%$ of the cooperatives reported that businesses had bought fresh paddy at higher prices; $45.8 \%$ of the cooperatives supposed that businesses had bought fresh rice at the price as the market's; And no cooperative answered that businesses had paid below the market price. Meanwhile, in the model of AC not participating in any form of LPF setup association (M2), only $39.2 \%$ of cooperatives responded that enterprises had purchased paddy at a higher price; $56.5 \%$ of cooperatives said that enterprises had purchased paddy at the same price level as the market price; $4.3 \%$ reported that they had 
paid lower price than the market price. For the FG model (M3), no cooperative group said that the enterprises used a price higher than of the market; $70 \%$ of surveyed respondents answered that enterprises had accepted an equal price to the market's; even 30\% CG thought that businesses had purchased at a lower price than the market's.

ii) The price of fresh paddy was higher in the Model 1 (by $471 \mathrm{VND} / \mathrm{kg}$ ), which exceed the price level in Model 2 (with the price of $300 \mathrm{VND} / \mathrm{kg}$ above average). According to the AC and CG, the higher price level that enterprises purchased is mainly thanks to the $\mathrm{AC}$ and FG having organized the production of high quality paddy on LPF as required by the purchasing enterprises. Therefore, AC in association to establish LPF help the selling price of rice become more profitable than that of other models.

The benefits of ACs joining in linking farmers to set up LPF:

The research findings have shown that the AC in association to build the LPF (M1) offered more benefits than the cooperatives in no association (M2) and FG model (M3). The benefits of the cooperatives include: i) Helping to enhance the role of cooperatives in service of members; ii) Enabling cooperatives to effectively organize crop production and harvesting; iii) Help improve cooperative capacity; iv) Make cooperatives easier to monitor and prevent diseases in crops; v) Helping cooperatives find and make contracts to associate rice consumption with enterprises easily; vi) Allowing cooperatives to make less effort in providing rice production services to for members; vii) Creating advantages for investment in production infrastructure: irrigation, intra-field traffic, warehouses; viii) Helping the cooperative to expand business activities to serve members.

In addition, thanks to association to set up LPF, the cooperatives also earn more from associate services, organizing the implementation of LPF with businesses. When linkage of famers to establish LPF, cooperatives are paid by the firms with a given amount of fee per kilogram of rice, which the firms buy via the cooperatives under the contract. This amount is agreed and signed by both the businesses and cooperatives, which is noted in the contract. According to the survey, in the AC joining LPF setup association model (M1), the firms paid this fee on an average of $52 \mathrm{VND} / \mathrm{kg}$ of fresh rice purchased via AC. As for the cooperatives not in association to establish LPF (M2) and famer groups (M3), businesses paid at lower level, being $20 \mathrm{VND} / \mathrm{kg}$ and $13 \mathrm{VND} / \mathrm{kg}$ respectively. The reason was that in order to carry out the association as required by the firms, the AC would have to take a lot of effort in organizing, monitoring and supervising the uniformed farming practices of farmer households. Moreover, if the AC or FG receive input supplies for the farmers (materials supported by the enterprise), AC or FG are simultaneously assisted with a percentage (\%) of commission to deliver the supplies to them (calculated in $\%$ of cash value of supplies). This commission rate is about $5-8 \%$.

\subsection{Advantages and difficulties of ACs in linking farmers to establish LPF in the Mekong Delta}

- The advantages of ACs in associating farmers to construct LPF include: i) Local authorities do planning for LPF; ii) Improve infrastructures of the LPF setup associated area. iii) Positive supports from local authorities: assist in finding and connecting with rice purchasing enterprises; Influence \& encourage farmer households to join in the link to set up LPF; Handle possible disputes; iv) Require less effort to encourage households to apply the uniformed technical process and switch rice varieties as requested by enterprises; v) Associated enterprises collect and purchase rice in a stable and timely manner.

- The difficulties that ACs may encounter in associating farmers to establish LPF are: i) The uniformed technical process of rice cultivation is too complicated that it can be difficult to alter the original farming habits of the farmer households; ii) Enterprises sign association contract but do not purchase at a higher price than the free market; iii) Farmer do not comply with the contract signed with the enterprises. This is a major obstacle for cooperatives as well as enterprises when signing association contracts to build LPF; iv) Enterprises do not make advance investment (cash, materials) in the form of deferred payment; Enterprises do not buy rice in time according to the notified schedule; Enterprises require the transportation of rice to the enterprise's warehouse but the cooperatives could not organize the rice transportation service; v) AC could not encourage households to apply uniformed technical process or switch rice varieties; and $\mathrm{AC}$ are incapable to organize rice production services for member households; vi) Other difficulties: no support policy from the State when AC attending the association to set up LPF; Poor quality infrastructure (canals, dikes, traffic) does not form the associate area.

\subsection{Determinants influencing the role of ACs in linking farmers to establish LPF in the Mekong Delta Internal determinants of ACs}

- AC management: The more management contents $\mathrm{AC}$ have, the bigger the role of $\mathrm{AC}$ in association to set up LPF. Specifically, AC has built up internal regulations such as financial management regulations, administrative regulations, etc with specific tasks assigned to each department, each member in the board of directors (BOD). Annually, AC develop feasible production plans and strategy. Periodically, AC make reports on business results, financial statements and tax reports to send to management agencies and announce to the members' congresses publicly and transparently. This indicates that the state policies needs to support the training of AC administrative staff on management skills; Assist AC to lend capital to expand production and 
business.

- Qualification, capacity of the AC's Chairman of the BOD: The capability of the Chairman of the BOD influences the role of $\mathrm{AC}$ in the implementation of LPF-establishing association. The capability of the Chairman is demonstrated by the capacity and experience in cooperative management, as well as the trust of the member households. In reality, many AC have their Chairman and Directors inadequate of professional qualifications (such as Tan Cuong Cooperative, the Chairman and also Director of the cooperative is 64 years old, 10/10 in educational level and lack of professional training). However, if they are enthusiastic, prestigious to members, experienced in managing and operating cooperatives, those $\mathrm{AC}$ are still able to develop significantly and provide numerous high quality services for the members.

- Capital of cooperatives: Cooperatives' capital significantly affects the role of cooperatives in the implementation of LPF setup association. Cooperatives possessing a large amount of capital mean that they can mobilize capital from their members; or cooperatives can borrow from credit institutions. In other words, AC must build a feasible plans and business projects so as to be approved by credit institutions. If a cooperative has abundant capital, it also means that the cooperative has a large business scale, thus is able to support members more efficiently. This implied that State policies need to assist cooperatives to get loans, encourage members to contribute capital to cooperatives to develop business and production.

- Assets of cooperatives: If cooperatives possess many assets and equipment to serve their members, cooperatives have major roles in the implementation of LPF set up association. Therefore, it is necessary to assist the cooperative in borrowing capital, investing in machinery and equipment to offer production services for affiliated farmer households such as soil tillers, rice cutters, transportation means; warehouse, rice drying system. Typically, Tan Cuong cooperative, thanks to the World Bank project: cooperative headquarters, warehouse, drying system, preservation and processing of rice, can organize post-harvest services for households easier. In another case, Duc Hue Cooperative encouraged members to contribute capital to purchase equipment and machinery for rice production: soil tillers, row machines, combined harvesting barges, rice transport.

- Benefits of farmer households in association: The more benefits the farmers gain when participating LPF set up association, the more major the role of cooperatives. This shows that the benefits of farmer households influence the role of cooperatives in LPF set up association for rice production.

\section{External determinants of ACs:}

- Supports from associated enterprises: The level of advance supports from enterprises to farmers and cooperatives (cash, materials) has a positive impact on the role of cooperatives. The more supports a company provide in advance, the more commitment it shows to the contract, and at the same time, expresses its high requirements for the LPF setup association conditions (seed varieties, production processes, seasonal production and harvesting). Consequently, the role and responsibility of the cooperatives in the association have to meet higher requirements to implement the association contract with the businesses, in the setting LPF. Overall, in order to promote the role of cooperatives in the association for LPF, the State policies should not only support cooperatives and farmer households, but also support enterprises to borrow preference loans for investment in the association to set up LPF.

- The State's supporting policies: the State's supporting policies affect the role of agricultural cooperatives. The fact that many agricultural cooperatives are operating effectively, associating to set up LPF efficiently was thanks to the supports from state policies. For example, Tan Cuong Cooperative was provided cooperative headquarters, warehouse, drying system, preservation and processing of rice; the Cooperative is assigned by the local People's Committee to manage the irrigation works, to serve watering pumping; land planning for centralized rice production; assist cooperatives in connecting with input material suppliers and rice traders. However, in recent time, State policies mainly offered rice varieties, technical guidelines for rice production for farmers to establish LPF, so few cooperatives were the supported. Therefore, in order for the AC to fulfill the role in the association to set up LPF, the State should support them in: education \& training to improve the management ability; access to loans; investment in equipment and machinery to provide of associated services for members; support with market linkages and contracts with businesses.

- The development of the agricultural market: The involvement of cooperatives in the association to build LPF is influenced by the development of the market. Generally, when the supply of produce exceeds demand the market can consume, the farmers need contracts. However, on the other hand, when the market demand is greater than the production supply, the enterprises generate a higher demand for association. Besides, the development of $\mathrm{AC}$ in the association is also strongly influenced by the process of globalization.

- Infrastructure conditions: Infrastructure such as roads, irrigation, electricity, warehouses, etc., plays an important role in the development of the production and consumption links of agricultural products. In fact, areas where infrastructure conditions are favorable, tend to have businesses and AC facilitated in investment and links of production and consumption of agricultural products 
4.4. Suggested solutions to enhance the role of ACs in linking farmers to set up LPF in the Mekong Delta Improving mechanism and policies to create a favorable environment for ACs to operate and promote their role in the linkages of agro-food value chains

- Improving the policies on developing linkages of agricultural product value chains with the participation of ACs: i) Improve the policies on developing linkages of production and consumption of agricultural products in the value chain; ii) Complete the associated credit policies, including credit policies for affiliated agricultural cooperatives; iii) Develop and complete the mechanisms and policies for accumulation of agricultural land to promote large-scale agricultural production; iii) Develop and improve mechanisms and policies to promote cooperative participation in the value chain; iv) Develop an agricultural insurance market linked to the association to set up large paddy fields.

- Planning and investing in upgrading the infrastructure of LPF production areas: i) The provincial People's Committees should stipulate the criteria for high-yield, centralized rice production and rice specialty production areas; ii) Planning and publicizing the planning of high-yield, centralized rice production and rice specialty production areas based on the survey and assessment of soil conditions, water resources and climatic conditions of each region and sub-region; iii) Invest in supporting infrastructure in high-yield, centralized rice production and rice specialty production areas: canals, inland traffics; iv) Encouraging farmers, enterprises and cooperatives to accumulate and concentrate land for facilitation of the setup of LPF, high-yield, centralized rice production areas and rice specialty production areas; v) Calling on enterprises to invest and build raw material areas, develop association with cooperatives and rice farmers; vi) Consulting \& supporting enterprises and agricultural cooperatives in the association to develop the setting up of LPF.

- Encouraging enterprises to associate with agricultural cooperatives to build set up large paddy fields: i) Provide favorable conditions and incentives for associated enterprises to lease land to build workshops, warehouses, storing and processing facilities; Assist the enterprises in land clearance cost, land rent reduction and exemption; ii) Provide preference interest rates to associated enterprises; iii) Consulting \& support enterprises to build projects for association to set up LPF with AC.

Strengthening the capacity and operating conditions of ACs to link farmer for LPF

- Training and improving management capacity of cooperative officers, especially the leader board: Training of the Chairman and Director of the cooperative as an entrepreneur on cooperative management, production \& business planning based on the advantages of cooperatives, market knowledge, market research, etc.

- Strengthening the management of cooperatives, allowing cooperatives to manage publicly and transparently: i) Consult, advise and support cooperatives in implementing public and transparent management; ii) Strengthen inspection of cooperatives on financial management and financial reporting to ensure that cooperatives comply with regulations; iii) Strengthening agricultural business support for cooperatives.

- Assisting ACs in access to loans, investment in assets and equipment for the association to set up large paddy fields: i) The State should ensure capital sources and priorities for cooperatives in association to establish LPF to borrow capital at preference interest rates so they can purchase assets \& equipment in service of the association to establish LPF; ii) Training \& guiding cooperatives to develop projects, plans for the association and make loan applications.

\section{Enhancing the role of ACs to represent the member households to establish LPFs}

- Assisting ACs to organize collective activities in setting up LPF and developing services, bringing benefits to the members: i) Guide AC to build the production \& business plans; ii) Support AC to implement the uniformed and sustainable cultivation technical processes (VietGAP, GlobalGAP,...); iii) Training and guiding members of cooperatives to apply technical processes meeting up with quality standards; partially covering the cost of certification of quality through $\mathrm{AC}$; iv) Consulting and guiding the cooperative to identify service demands of members; identifying the ability to meet service demands of cooperatives; developing measures / plans for service provision of cooperatives; v) Guiding cooperatives to conduct farmer service provision to support farmer households participating in the association to build LPF.

- Encouraging the participation of local authorities and mass organizations: i) Regulations on dispute resolution as well as support for the participation of the members of the Fatherland Front are also as significant as mediation organization. Encouraging and supporting the commune-level political associations to participate in mediation and settlement when there are disputes; ii) Local Committees and authorities should assign and delegate tasks to commune-level political associations to support and monitor the cooperation contracts in LPF area.

- Promoting communication to help farmers understand the benefits when participating in cooperatives and in the LPF set up association, so that they can voluntarily participate in. Notifying information of State policies and mechanisms on LPF set up association development and on the planning of the LPF areas and highyield rice production areas. Political associations should organize information, propaganda, counseling and support for members and strictly implement association contracts. 
- Supporting the development of pilot models and guiding documentation for ACs to expand association to set up LPF: i) Support the development of pilot models for AC to expand the association, which provide the background for assessments and summaries to draw on experience; ii) Develop guidelines for association implementation so that stakeholders can clearly understand the mechanism, roles and responsibilities of each party, creating transparency and facilitation.

\section{Conclusion}

ACs play an important role in centralized mass production of commodities. The participation of cooperatives in the association to establish LPF help facilitate and exploit the association's benefits for both farmer households and businesses. They are also suitable with the current conditions of agricultural production in Vietnam. Additionally, ACs in the association help businesses reduce associated costs and allow small-scale farmer households to increase competitiveness in the market, in terms of quantity, quality and price.

In the context of minor and scattered production in Vietnam, it is necessary to organize the development of ACs in the association to establish LPFs. In order to enhance the role of ACs in such association in the Mekong Delta, the following groups of solutions should be synchronizedly adopted: i) Improving mechanisms and policies for ACs to promote their role in association to set up LPF: credit; land; agricultural insurance; encourage businesses to associate with ACs; planning and investing in upgrading the infrastructure of the associated areas; ii) Strengthening the capacities of managers of ACs: educating, training; support public and transparent administration; assist the cooperatives to borrow capital to invest on equipment and machinery for production and business; iii) Enhancing the role of ACs representing members to implement association to set up LPF: support ACs in collective activities and provide services; encourage the participation of organizations and unions; enhancing influence and advocacy; support to develop pilot models and guidance documentation for ACs to expand the association to establish LPFs.

\section{References}

Chu, T.Q. (2012), Role and Solutions to Enhance the Role of Cooperatives in Agricultural and Rural Cooperatives in Vietnam, Agricultural Publication, Hanoi.

Dardak, R.A. (2015), Cooperative Movement in the Supply Chain of Agricultural Products: Way Forwards, International Seminar on Improving Food Marketing Efficiency-the Role of Agricultural Cooperatives.

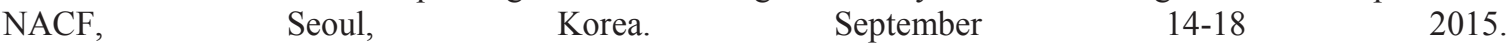
http://www.fftc.agnet.org/activities.php?func=view\&id=20150827153204.

Do, K.C. (2012), "Large Fields of Agriculture: Some Theoretical Issues and Developmental Practices," Journal of Economic Research, 413, 55-60.

Eaton, C. and Shepherd, A.. (2001), Contract farming: Partnerships for Growth, FAO Agricultural Services Bulletin 145.

Falco, S.D., Smale, M., Perrings, C. (2008), The role of agricutural cooperatives in sustaining the wheat diversity and productivity: the case of southern Italy, Environmental and Resource Economics, 39(2), 161174. https://doi.org/10.1007/s10640-007-9100-0.

Ho, D.B. (2014), "Provincial total factor productivity in Vietnames agriculture and Its determinants", Journal of Economics and Development, 16(2), 5-20.

Hoang, V.Q., Nguyen, T.D. (2016), Report on research results: Development of cooperatives and cooperative groups for linking rice production and consumption with big fields in Ca Mau, Bac Lieu, Soc Trang, An Giang, Report on survey results in 4 provinces of Ca Mau, Bac Lieu, Soc Trang and An Giang, implemented by GIZ, 2017.

ILO (2009), Value Chain Development Briefing Paper 2: The Role Of Cooperatives And Business Associations In Value Chain Development.

Ministry of Agriculture and Rural Development (MARD) (2014), Circular No. 15/2014 / TT-BNNPTNT, dated 29/4/2014 by the Ministry of Agriculture and Rural Development on guiding the implementation of some articles of Decision No. 62/2013 / QD-TTg dated 25/10/2013 of the Prime Minister.

Motamed, M.K. (2010), "Role of cooperative companies in sustainable rice production and poverty alleviation in Guilan state of Iran", African Journal of Biotechnology, 9(11), 1592-1599.

Prime Minister (2013), Decision No. 62/2013 / QD-TTg, dated 25/10/2013, of the Prime Minister on Policies To Encourage The Development Of Cooperation, Production Linkage With Agricultural Production And Establish Large Paddy Fields.

Pratiwi, Y.S.I. (2015), The Role of Farrmer Cooperatives in the Development of Coffee Value chain in East Nusa Tenggara Indonesia, The thesis submitted in partial fulfilment of the requirements for the joint academic degree of International Master of Science in Rural Development from Ghent University (Belgium). 2015.

Song, Y., Qi, G., Zhang, Y. \& Vernooy, R. (2014), "Farmer cooperatives in China: diverse pathways to 
sustainable rural development", International Journal of Agricultural Sustainability, 12(2), 95-108.

Tang, M.L. (2012). Large field development in new rural construction. Conference material "Cánh đồng mẫu lớn", July 2012 in Hanoi.

The Prime Minister (2013), Decision No. 899 / QD-TTg dated 10 June 2013 of the Prime Minister Approving The Project On Restructuring Agriculture Towards Higher Value Added And Sustainable Development.

Tosun, D., Yercan, M., Demirbas, N. (2013), "The place and importance of cooperatives in Food supply chain in Turkey", Proceedings-24th International Scientific-Expert Conference of Agriculture and Food IndustrySarajevo, 2013, 511-515.

Tran, D. N. (2012), Model Research: Farmer-farmer linkages in the Mekong Delta, Lab Publishing House. Vu, T.B. (2013), Large Sample Fields: Theoretical and Practical Approaches in the World and Vietnam. 